\title{
Enzyme assays in diseases of the heart and skeletal muscle
}

\author{
SIDNEY B. ROSALKI \\ From St Mary's Hospital, London

\section{Disease of the heart}

Heart tissue injury may release cardiac enzymes into the circulation and elevate serum enzyme levels (LaDue, Wróblewski, and Karmen, 1954). Many enzymes become raised, but three enzymesaspartate aminotransferase (EC 2.6.1.1), creatine kinase (EC 2.7.3.2), and lactate dehydrogenase (EC 1.1.1.27)-have proved of particular diagnostic value. In addition, determination of lactate dehydrogenase isoenzymes by electrophoresis or other methods may be helpful, as may be the combined estimation of alanine aminotransferase (EC 2.6.1.2) and aspartate aminotransferase.

\section{Enzyme Determinations in Suspected Myocardial Infarction}

Determination of cardiac enzymes is most frequently required for confirmation of suspected myocardial infarction. Diagnosis requires knowledge of enzyme changes following infarction, of enzyme changes produced by other cardiac diseases and pulmonary causes of chest pain, and also of the non-cardiopulmonary conditions which may also result in enzyme elevation.

\section{ASPARTATE AMINOTRANSFERASE}

Elevation of this enzyme in serum commences some six to eight hours after infarction, reaches a peak after 24 hours, and returns to normal on average by the fifth day (LaDue and Wróblewski, 1955). If serial determinations are made within four days of infarction, elevated values are found in over $95 \%$ of patients (Agress, 1959). But, if initial sampling is delayed to the fourth day the test becomes unreliable.

\section{CREATINE KINASE}

This enzyme begins to increase in serum within three to six hours of myocardial infarction, reaches a peak at 24 hours, and returns to normal on average by the third day (Dreyfus, Schapira, Resnais, and Scebat, 1960). The early elevation is advantageous in p $\overrightarrow{\mathrm{er}}-$ mitting early diagnosis and the selection of cases for admission to intensive care units (Smith, 1967). कूn most published series raised levels were found in approximately $90 \%$ of cases of myocardial infarction. This is lower than that found with aspartate aminotransferase because blood sampling is frequently possible within the short period of increased creat kinase activity. However, both enzymes are found 40 to be raised with equal frequency when samplès obtained within the first 48 hours are compgred (Smith, 1967).

\section{LACTATE DEHYDROGENASE}

Elevation of serum lactate dehydrogenase commen⿳⺈⿴囗十 some 12 hours after infarction, reaches a peak af 48 hours, and returns to normal on average by the 11 th day (Wacker, Ulmer, and Vallee, 1956; Kiḡg and Waind, 1960). This delayed return is valuable if a blood sample cannot be obtained soon after the infarct. A raised level is found in more than $95 \%$ of cases and, when initial sampling is carried opit after the third day, is more frequent than elevationif aspartate aminotransferase.

\section{ENZYME LEVELS AFTER INFARCTION}

The degree of enzyme elevation following infarction varies with each enzyme. The most sensitive creatine kinase, for which raised values average some seven to 10 times the upper limit of norma ; next comes aspartate aminotransferase followed by lactate dehydrogenase. With all these enzymes, the smaller the infarct the lower is the peak enzyme level. With low peak values the serum enzyme levells return to normal sooner than the average figures quoted above (LaDue and Wróblewski, 1953; Rosalki, 1963), but in the case of lactate dehydrogenase a return to normal within five days of $\overrightarrow{\mathrm{in}}$ farction is very uncommon. 
PROGNOSTIC VALUE OF ENZYME DETERMINATIONS

The degree of enzyme elevation has some prognostic significance (Chinsky and Sherry, 1957), and higher mortality rates in the early (within six weeks) and late (two and five year follow-up) post-infarctive period occur with high enzyme levels (Kibe and Nilsson, 1967). For example, patients with aspartate aminotransferase values greater than 150 IU or lactate dehydrogenase (pyruvate $\rightarrow$ lactate methods) above $1,000 \mathrm{IU}$ per litre at $25^{\circ} \mathrm{C}$ show mortality figures more than twice those of patients with peak serum enzyme levels below these figures (Rosalki, 1963).

SUGGESTED SCHEDULE FOR DIAGNOSIS OF INFARCTION BY ENZYME ASSAY

For the diagnosis of myocardial infarction it is recommended that a blood sample should be taken as early as possible after infarction followed by two additional samples at intervals of 24 hours. This routine has the advantage that transient enzyme changes will not be missed and that peak enzyme levels can be assessed for use as a guide to prognosis. Where initial sampling is delayed, or elevation above the normal range is slight, a rise or fall in enzyme levels greater than the normal variation per day may provide diagnostic confirmation. With careful methodology such variation in normal subjects does not exceed $7 \mathrm{IU}$ per litre at $25^{\circ} \mathrm{C}$ for aspartate aminotransferase (Goble and O'Brien, 1958 ), or 40 IU per litre for lactate dehydrogenase (pyruvate $\rightarrow$ lactate methods) (Nutter, Trujillo, and Evans, 1966). Similarly, variation of creatine kinase (creatine phosphate $\rightarrow$ creatine methods) does not normally exceed $10 \mathrm{IU}$ per litre at $25^{\circ} \mathrm{C}$ on ambulant sedentary subjects; levels of this enzyme normally fall with bed rest (Griffiths, 1966) but a rise exceeding this value may be significant.

It is advisable to carry out at least two enzymatic procedures to guard against the possibility of methodological error. In the first $\mathbf{4 8}$ hours following infarction the combination of aspartate aminotransferase and creatine kinase would be the logical choice. After this, a combination of the former with lactate dehydrogenase or its isoenzymes is preferable. With this regime, elevated serum enzyme activity can be detected in over $95 \%$ of patients with recent myocardial infarction. This figure can be compared with the much lower figures generally quoted for definitive diagnosis by clinical means alone $(80 \%)$, by electrocardiographic examination alone $(80 \%)$, and by combined clinical and ECG examination $(90 \%)$ (Kibe and Nilsson, 1967).
DIFFERENTIAL DIAGNOSTIC ROLE OF LACTATE DEHYDROGENASE ISOENZYMES AND ALANINE AMINOTRANSFERASE DETERMINATION Whilst enzyme changes provide convenient confirmation of suspected infarction, and the diagnosis of infarction must be suspect in their absence, it must not be forgotten that other cardiac, chest, and non-cardiopulmonary disorders may also result in serum enzyme elevation.

It is in the differential diagnosis of myocardial infarction from other causes of enzyme elevation that lactate dehydrogenase (LD) isoenzyme determination and the assay of both the aspartate and alanine aminotransferases prove helpful. Separation of the isoenzymes of creatine kinase and aspartate aminotransferase is not of diagnostic value.

\section{LACTATE DEHYDROGENASE ISOENZYMES}

The lactate dehydrogenase of human somatic tissues can be separated by electrophoresis into five isoenzymes (Wieland and Pfleiderer, 1957). The band moving fastest towards the anode is designated fraction 1 , and the remaining fractions are numbered consecutively - fraction 5 being the slowest moving. The relative proportions of the isoenzymes vary with the tissue of origin. Heart, kidney, and red cells contain mainly the fastest moving isoenzymes, $L D_{1}$ and $\mathrm{LD}_{2}$. Lung contains isoenzymes of intermediate mobility, $\mathrm{LD}_{2}, \mathrm{LD}_{3}$, and $\mathrm{LD}_{4}$. Liver contains mainly the slowest moving isoenzyme, $\mathbf{L D}_{5}$, and this isoenzyme is generally the most prominent in skeletal muscle, although other fractions are present (Wieme, 1959; Wróblewski, Ross, and Gregory, 1960).

In normal serum $L D_{1}, L_{2}$, and $L_{3}$ are readily detected, $\mathrm{LD}_{2}$ being the most prominent fraction. When serum total LD activity is raised, the isoenzyme fractions corresponding to those most prominent in the involved tissues are also increased. Therefore after myocardial infarction it is the fast moving isoenzymes, particularly $\mathrm{LD}_{1}$, that are found to be raised (Vesell and Bearn, 1957; Wróblewski et al, 1960), the characteristic alteration being an $\mathrm{LD}_{1}$ level that is equal to or exceeds that of $\mathrm{LD}_{2}$ (Cohen, Djordjevich, and Ormiste, 1964; Moller and Raabo, 1964). When this LD isoenzyme pattern is found in serum, it suggests that LD elevation is of cardiac origin and this may assist differentiation from other disorders which result in elevation of total LD activity but with a different isoenzyme pattern (Table I). It should be remembered, however, that megaloblastic anaemia, acute haemolysis, renal infarction, and sometimes the Duchenne type of muscular dystrophy (Englhardt-Gölkel, Löbel, Seitz, and Waller, 1958; Wróblewski and Gregory, 1961; Richterich et al, 1961; Cohen et al, 1964) may produce a similar alteration in LD isoenzyme patterns. 


\begin{tabular}{|c|c|c|c|c|c|}
\hline & $\begin{array}{l}\text { Aspartate Amino- } \\
\text { transferase }\end{array}$ & $\begin{array}{l}\text { Alanine Amino- } \\
\text { transferase }\end{array}$ & $\begin{array}{l}\text { Lactate Dehydro- } \\
\text { genase }\end{array}$ & Isoenzymes & Creatine Kinase \\
\hline Liver disease & + & + & \pm & $\mathbf{L D}_{5}$ & - \\
\hline Prolonged hypotension & + & + & \pm & $\mathbf{L D}_{5}$ & - \\
\hline Acute pancreatitis & + & + & \pm & $\mathbf{L D}_{5}$ & \pm \\
\hline Renal infarction & + & - & + & $\mathbf{L D}_{1}$ & \pm \\
\hline Acute haemolysis & + & \pm & + & $\mathrm{LD}_{1}$ & - \\
\hline Megaloblastic anaemia & - & \pm & + & $\mathbf{L D}_{1}$ & - \\
\hline Disseminated malignancy & + & + & + & L. $D_{3,4,5}$ & - \\
\hline Cerebrovascular disease & + & - & - & - & + \\
\hline Muscle disease or trauma & + & + & + & $\mathbf{L D}_{1}$ or $_{5}$ & + \\
\hline Hypothyroidism & - & - & - & - & + \\
\hline Acute psychoses & - & - & - & - & + \\
\hline Drug toxicity & \pm & \pm & \pm & $\mathbf{L D}_{5}$ & \pm \\
\hline
\end{tabular}

Table I Non-cardiopulmonary diseases causing serum enzyme elevation ${ }^{1}$

$+=$ frequen $t$ enzyme elevation $\pm=$ occasionally elevated $-=$ elevation absent or rare

Provided these conditions are remembered, they are not likely to be a source of diagnostic confusion with cardiac disease.

LD isoenzyme examination is normally carried out by electrophoresis of serum, isoenzymes being demonstrated by staining, and a quantitative assessment of the stained bands being made densitometrically. However, several non-electrophoretic techniques are available. Amongst the most popular are the heat treatment of serum, determination of serum alpha-hydroxybutyrate dehydrogenase ${ }^{1}$ activity, and the measurement of urea-stable LD activity.

HEAT-STABLE LACTATE DEHYDROGENASE The slow moving LD isoenzymes are relatively heatlabile so that measurement of heat-stable LD activity in serum provides a measure of the fast moving isoenzymes.

ALPHA-HYDROXYBUTYRATE DEHYDROGENASE (HBD)

If 2-oxobutyrate is substituted for pyruvate as substrate for LD it is preferentially reduced by the faster moving LD isoenzymes (Rosalki and Wilkinson, 1960 ), and estimation of this activity in serum is another way of measuring the proportion of the faster LD isoenzymes.

\section{UREA-STABLE LACTATE DEHYDROGENASE}

The addition of urea, generally at a final concencentration of $2 \mathrm{M}$, to the substrate used for $\mathrm{LD}$ determination inhibits slow moving LD isoenzymes (Richterich, Burger, and Weber, 1962). Measurement of urea-stable LD thus provides another measure of fast moving LD isoenzymes in serum.

The ability of all these procedures to discriminate between LD elevation due to fast or slow moving LD isoenzymes in serum is very similar, with measurement of urea-stable LD activity perhaps 'That is, 2-hydroxybutyrate dehydrogenase. showing some marginal advantage. The choice of determination must thus be a matter for individuat laboratory preference. The author prefers $\mathrm{HBB}$ determination, and many years' experience with the method has shown it to be a reliable diagnostio procedure. However, since batches of substrate and co-enzyme (reduced NAD) may contain enzyme ine hibitors which affect the fast moving isoenzymes more than the slow and (in the case of the cQ enzyme) HBD more than LD (Rosalki; unpublished data), the use of inhibitor-free reagents in all procedures is essential.

The advantages of LD isoenzyme procedures threefold. First, they increase the diagnosti specificity and sensitivity of LD determination $b \bar{D}$ their preferential measurement of the fast moving LD isoenzymes; second, they permit earlier diagnosis than is possible with total LD determination alon $\overrightarrow{\mathbb{S}}$ because the $L D_{1}$ isoenzyme fraction may be elevate whilst total LD activity still remains within the normal range; and third they may permit diagnosis. of infarction after total LD activity has returned to normal, for $L_{1}$ activity may remain elevated sever $\not \Phi$ days longer, elevation sometimes extending into the third or fourth week following infarction.

Whilst these procedures usefully extend the value of total LD determination, it is the author's opinion that they are all less informative than full isoenzyme determination and quantitation by electrophoresis This alone is helpful in determining when $L D^{2}$. isoenzymes of intermediate mobility are responsible for total LD elevation and is also the only procedures which can conveniently and sensitively demonstrate combined elevation of anodic and cathodic fractions

ALANINE AMINOTRANSFERASE

The combination of determination of this enzym $\Phi$ with that of aspartate aminotransferase is helpful in differentiating a high serum level of the latter of cardiac origin from one of hepatic origin (Wróblewski 
and LaDue, 1956). In liver disorders there is frequently a similar increase of both aminotransferases. However, in the early period following myocardial infarction, elevation of alanine aminotransferase is absent or minimal. It may become more prominent some days after infarction, largely as a result of liver damage, and this elevation may become pronounced if shock or congestive cardiac failure complicates infarction

ENZYME CHANGES IN CARDIAC DISORDERS OTHER THAN MYOCARDIAL INFARCTION

\section{Angina of effort}

In this condition no alteration of serum enzyme levels takes place (LaDue and Wróblewski, 1955).

\section{Acute coronary insufficiency}

In patients with prolonged cardiac pain but without other clinical or ECG evidence of infarction (which is presumed not to occur), increased enzyme activity in serum is observed in more than $10 \%$ of cases (Goble and O'Brien, 1958; Agress, 1959; Resnik, 1962). The levels generally remain less than twice the upper limit of normal and when LD is elevated it is the $\mathrm{LD}_{1}$ fraction that is increased. Occasionally the elevation is delayed until the fourth to 10th day following the attack. Whether the relatively small rise in serum enzymes indicates some myocardial necrosis is unknown although this is generally assumed.

\section{Pericarditis}

Serum enzyme levels are normal in more than $90 \%$ of patients (Agress, 1959). Where raised values are found, minor myocardial damage is thought to be the reason.

\section{Myocarditis}

This may be accompanied by raised serum enzyme levels if the condition is active (Nydick, Tang, Stollerman, Wróblewski, and LaDue, 1955; Chesler, 1958). $L D_{1}$ activity is prominent when total LD activity is elevated (Cohen et al, 1964).

\section{Paroxysmal cardiac arrhythmias}

In the absence of infarction, these show elevation of serum aspartate aminotransferase in more than $20 \%$ of patients who develop heart rates exceeding 140 per minute and lasting for more than $\mathbf{3 0}$ minutes (Runde and Dale, 1966). Elevation is generally the result of hepatic congestion so that elevation of alanine as well as aspartate aminotransferase is usually present, levels of the latter generally not exceeding $40 \mathrm{IU}$ per litre at $25^{\circ} \mathrm{C}$. Both creatine kinase and lactate dehydrogenase are usually normal but, should the latter be elevated, it is generally the $\mathrm{LD}_{5}$ fraction which is found to be increased. Occasionally, pulmonary congestion causes elevation of intermediate LD isoenzymes, or impairment of coronary perfusion may result in release of cardiac isoenzymes.

\section{Chronic congestive cardiac failure}

About $15 \%$ of patients with chronic congestive cardiac failure are found to show elevated aspartate aminotransferase and lactate dehydrogenase levels. This results from liver damage (Agress, 1959) so that it is the $L D_{5}$ fraction that is increased and elevation of the alanine aminotransferase is common, though all three generally remain below twice the upper limit of normal. Creatine kinase activity remains normal.

SOME ENZYME CHANGES IN NON-CARDIAC CAUSES OF CHEST PAIN

Three conditions deserve special consideration because of the possibility of confusion with myocardial infarction. These are pulmonary infarction, pneumonia, and dissecting aortic aneurysm.

\section{Pulmonary infarction}

As a result of pulmonary infarction aspartate aminotransferase is elevated in some $25 \%$ of patients (Agress, 1959). The increase is usually small, the levels rarely exceeding $40 \mathrm{IU}$ per litre at $25^{\circ} \mathrm{C}$, and occurs only in severe cases, frequently being delayed until the fourth day. In myocardial infarction of comparable severity more pronounced changes are usual. It is not easy to assess the incidence of LD elevation following pulmonary infarction, because of widely diverging reports, possibly due to varying methodology. It appears that minor degrees of elevation are a frequent but inconstant accompaniment. Elevation, of the $L D_{1}$ fraction as a result of accompanying haemolysis of red cells in the infarcted lung tissues, of $\mathrm{LD}_{5}$ as a result of liver damage from hepatic congestion, or of $\mathrm{LD}_{2}, \mathrm{LD}_{3}$, and $\mathrm{LD}_{4}$ released from the damaged lung tissue itself, may be observed (Cohen et al, 1964). Creatine kinase activity remains normal.

\section{Pneumonia}

In pneumonia, aspartate aminotransferase and creatine kinase generally remain normal. Reports of elevation of the latter in pulmonary disease have frequently been traced to release of the enzyme from muscle damaged by intramuscular injections. Lung tissue itself contains minimal amounts of this enzyme. Up to one third of patients with pneumonia may show elevated total LD activity but such elevation is slight; the $\mathrm{LD}_{1}$ fraction may be increased (Mager, Blatt, and Abelmann, 1966) presumably as a result of intrapulmonary red cell breakdown. 
Acute dissecting aortic aneurysm

Acute dissection of the aorta is generally unaccompanied by an alteration in serum cardiac enzyme levels unless the aortic arch is involved. When this occurs, more than a third of patients show increased enzyme activity which may reach very high levels (Wilkie, 1969). This is believed to result from heart muscle damage secondary to occlusion of the coronary orifices.

NON-CARDIOPULMONARY DISEASES CAUSING SERUM ENZYME ELEVATION

Non-cardiopulmonary conditions which may result in serum enzyme elevation are listed in Table $I$. Provided that they are remembered, they rarely cause confusion in the diagnosis of myocardial infarction.

COMPARATIVE VALUE OF ASSAYS OF SERUM ASPARTATE AMINOTRANSFERASE, LACTATE DEHYDROGENASE, AND CREATINE KINASE IN DIFFERENTIAL DIAGNOSIS

It seems appropriate at this point to sum up briefly the value of assays of these enzymes in serum in differentiating myocardial infarction from other disorders.

Aspartate aminotransferase activity is raised in a variety of conditions in many of which liver damage is a feature. Concomitant elevation of alanine aminotransferase helps to identify the latter.

Elevation of lactate dehydrogenase occurs in as wide a variety of conditions as the aspartate aminotransferase. However, elevation of the $\mathrm{LD}_{1}$ isoenzyme, which is found mainly in the heart, red cells, and kidney, limits the number of non-cardiac disorders which need be considered.

Creatine kinase activity possesses the highest degree of specificity. It is not elevated in liver disease, blood diseases, or malignant diseases nor is elevation a feature of pulmonary disease. It must, however, be remembered that spurious elevation may result from intramuscular injections (Hess, MacDonald, Frederick Jones, Neely, and Gross, 1964) and that raised levels may follow recent, prolonged and severe exercise (Griffiths, 1966).

DIAGNOSIS OF RECURRENCE OF MYOCARDIAL INFARCTION

Should myocardial infarction recur in the early postinfarction period, renewed elevation of serum enzymes takes place (LaDue and Wróblewski, 1955). The ECG diagnosis of re-infarction may be impossible because of persistence of the ECG changes of the initial infarction. Renewed elevation of serum creatine kinase is the most easily detected serum enzyme change, since this is the first serum enzyme to return to normal following the initial episode.
DIAGNOSIS OF MYOCARDIAL INFARCTION THE EARLY POSTOPERATIVE PERIOD Myocardial infarction occurring during the ear postoperative period is an important condition and carries a high mortality (Dack, 1963) It is mos frequent within three days of operation, the incidenç being highest in major operations on older subjecE् with a previous history of cardiac disorder. Enzym elevation during the postoperative period ma result from operative trauma alone, and the readi ness with which creatine kinase increases aftê muscle trauma renders this enzyme valueless for the detection of myocardial infarction in the early postoperative period. The fast moving $\mathbf{L} \overrightarrow{\mathrm{g}}$ isoenzyme shows the least elevation as a result of: operative trauma (Killen, 1968) whereas this fraction is, typically, consistently elevated following in farction. Determination of $\mathbf{L D}_{1}$ would therefore ap= pear to be the procedure of choice in this diagnos tic situation, but some reports suggest that pos? operative infarction may occur with only minima changes in this fraction (Hunter, Endrey-Walder, Bauer, and Stephens, 1968).

D-GLUTAMYLTRANSFERASE (EC 2.3.2.1 ACTIVITY AFTER MYOCARDIAL INFARCTION The enzyme D-glutamyltransferase ${ }^{2}$ has been foun $\vec{b}$ to show protracted elevation following myocaregia infarction (Agostoni, Ideo, and Stabilini, 195ं Hedworth-Whitty, Whitfield, and Richardson, 196्大 7 ? raised values occurring after the fourth day ân persisting for up to a month. Whilst such changes are frequent following infarction, and are unusuqf following cardiac pain without infarction (Rosalk? Rau, Lehmann, and Prentice, 1970), they must be interpreted with caution because raised values are also found in liver disease and chronic ischaemio heart disease.

The source of the elevation following myocardia infarction is uncertain but in most cases is thought to be the liver, hence the test cannot be regarded as. reliable indication of either infarction or ischaemig heart disease. D-glutamyltransferase activity is negligible in normal heart tissue and though a@ increase in cardiac content following infarction has been reported in animal studies (Ravens Gudbjarnason, Cowan, and Bing, 1969) the autho has examined several infarcted human hearts with out observing any significant enzyme activity.

Other Applications of Enzyme Determinations Cardiac Disease

DIAGNOSIS OF CARDIAC TRANSPLANT REJEC TION

Measurement of serum LD activity has been claimę ${ }^{2}$ Also known as $\gamma$-glutamyltranspeptidase. 
to be of value in the diagnosis of cardiac transplant rejection, particularly in the first month when ECG changes are unreliable. Rejection may be signified by $L_{1}$ activity exceeding that of $L_{2}, L D_{1}$ activity greater than $35 \%$ of total $L D$ activity, and $L_{1}$ activity more than twice the upper limit of normal for this fraction (Nora, Cooley, Johnson, Watson, and Milam, 1969). However, LD alteration resulting from operation, from the use of extracorporeal circulation or from immunosuppressant drugs may obscure the interpretation of post-transplant LD changes.

ASSESSMENT OF CARDIOTOXIC EFFECT OF DRUGS

Serum enzyme determinations have been used to

\section{Diseases of skeletal muscle}

Disorders of skeletal muscle include those which are secondary to an abnormality of motor innervation, and the myopathies, which are primary disorders of skeletal muscle. As a group the myopathies are uncommon and include conditions of exceptional rarity. The most important myopathies clinically are the dystrophies, polymyositis, and myopathies associated with metabolic or endocrine disorders.

In the myopathies, enzymes may be released from muscle and increased serum enzyme activity may result. When this occurs raised levels of creatine kinase (Ebashi, Toyokura, Momoi, and Sugita, 1959), ketose 1-phosphate aldolase ${ }^{3}$ (EC 4.1.2.7) (Sibley and Lehninger, 1949), lactate dehydrogenase (Schapira and Dreyfus, 1957), and aspartate and alanine aminotransferases (Dreyfus and Schapira, 1955) may all be found. In every variety of myopathy, however, creatine kinase is the serum enzyme most frequently raised and shows the greatest degree of elevation, so that assay of this enzyme is the assay of choice for the investigation of muscle disease. The changes that occur in some important myopathies and in other muscle disorders from which they must be differentiated are summarized in Table II.

\section{Serum Creatine Kinase Activity in Myopathies}

\section{MUSCULAR DYSTROPHY}

The muscular dystrophies are genetically determined primary degenerative disorders of muscle. The most important varieties are the Duchenne, the limb-

${ }^{1}$ Commonly known as aldolase or fructose 1-phosphate aldolase. assess the cardiotoxic effects of drugs. Patients treated with emetine derivatives have sometimes been monitored in this way (Dempsey and Salem, 1966).

DETECTION OF INTRAVASCULAR HAEMOLYSIS RESULTING FROM LEAKING HEART-VALVE PROSTHESES

Leakage of ball-valve prostheses used to replace heart valves is accompanied by intravascular haemolysis. Such haemolysis liberates red cell LD and results in elevated serum activity, which can be used to assess the degree of haemolysis and to detect valve leakage (Myhre and Rasmussen, 1970).

\begin{tabular}{|c|c|}
\hline & Change $^{2}$ \\
\hline \multicolumn{2}{|l|}{ Myopathy } \\
\hline Dystrophy & + to +++ \\
\hline Polymyositis & - to +++ \\
\hline \multicolumn{2}{|l|}{ Metabolic myopathies } \\
\hline McArdle etc & \pm \\
\hline Alcoholic & + \\
\hline Thyrotoxic & - \\
\hline Steroid & - \\
\hline \multicolumn{2}{|l|}{ Disorders of motor innervation } \\
\hline Werding-Hoffman & - to \pm \\
\hline Benign congenital hypotonia & \\
\hline Kugelberg-Welander syndrome & - to + \\
\hline Motor neurone disease & - to \pm \\
\hline Poliomyelit is & - \\
\hline Polyneuritis & - \\
\hline Myasthenia gravis & - \\
\hline \multicolumn{2}{|l|}{ Trauma } \\
\hline including intramuscular injections and surgery & + to +++ \\
\hline $\begin{array}{l}\text { Convulsive disorders } \\
\text { including epilepsy and tetanus }\end{array}$ & + \\
\hline
\end{tabular}

Table II Creatine kinase in muscle disease ${ }^{1}$

'Elevation of muscular origin is also found in hypothyroidism, hypothermia, cerebrovascular disease, and psychotic disorders. Physiological elevation occurs after exercise, in early childhood and in early postpartum period. An increase of cardiac origin is found in heart disease.

${ }^{2}+=$ elevation, $+++=$ marked elevation, $\pm=$ mild, inconstant elevation, $-=$ normal.

girdle, and the facioscapulohumeral dystrophies, of which the Duchenne dystrophy is the commonest and the most severe. Each is characterized by progressive weakness and wasting of proximal skeletal muscles. The clinical features of these dystrophies are summarized in Table III. 


\begin{tabular}{|c|c|c|c|}
\hline & Duchenne & Limb-girdle & Facioscapulohumeral \\
\hline $\begin{array}{l}\text { Age of onset } \\
\text { Pseudohypertrophy } \\
\text { Distribution } \\
\text { Usual mode of transmission } \\
\text { Expression } \\
\text { Progression } \\
\text { Disablement } \\
\text { Death }\end{array}$ & $\begin{array}{l}\text { 0-5 years } \\
\text { Usual } \\
\text { Pelvis, shoulders } \\
\text { Sex-linked recessive } \\
\text { Males } \\
\text { Rapid } \\
\text { Within } 10 \text { years } \\
\text { 10-20 years }\end{array}$ & $\begin{array}{l}\text { Childhood } \\
\text { Occasional } \\
\text { Pelvis, shoulders, face } \\
\text { Autosomal recessive } \\
\text { Male or female } \\
\text { Variable } \\
\text { Within } 30 \text { years } \\
30-50 \text { years }\end{array}$ & $\begin{array}{l}\text { Adolescence } \\
\text { Infrequent } \\
\text { Face, shouiders, pelvis } \\
\text { Autosomal dominant } \\
\text { Male or female } \\
\text { Slow } \\
\text { - } \\
\text { Normal age }\end{array}$ \\
\hline
\end{tabular}

Table III Clinical features of muscular dystrophies (after Pearson, 1963)

\section{Duchenne dystrophy}

In Duchenne dystrophy elevated serum creatine kinase activity is a constant feature and is a prerequisite for diagnosis. The highest values occur in early childhood (Okinaka, Kumagai, Ebashi, Sugita, Momoi, Toyokura, and Fujie, 1961), elevation averaging some 70 times normal. Enzyme levels may be of prognostic importance (Dreyfus, Schapira, and Schapira, 1958), for it is suggested that the higher the value relative to the age of the child, the more rapid the progression of the disease. With progression, the serum activity falls as a result of loss of muscle mass from which enzymes can leak into the serum, and also because of reduced patient activity. Even in chair-bound or preterminal patients, however, some elevation persists.

Determination of this enzyme in serum permits diagnosis of Duchenne dystrophy years before it becomes apparent clinically. Very high enzyme levels have been noted in symptomless children with a family history of the disorder, who have subsequently developed the disease (Aebi, Richterich, Stillhart, Colombo, and Rossi, 1961). Conversely, the finding of persistently normal serum activity in early childhood may be used to reassure parents that the disorder will not develop. Reliable diagnostic information has been obtained as early as the age of 3 months.
Duchenne dystrophy is transmitted as a sex-linked $\overrightarrow{\mathbb{P}}$ recessive disease by female carriers who are clinically normal or near normal. Approximately 1 in 5,000 females are carriers of the disorder, and half the sons of such carriers will develop the disease, and half the daughters will be carriers. Serum creatin $\vec{e}$ kinase assay is the procedure of choice for the detection of the carrier state and thereby assisto genetic counselling. Over $80 \%$ of symptomless female carriers of Duchenne dystrophy show raise values, the highest incidence and levels occurring in younger subjects (Thompson, Murphy, and Mc. Alpine, 1967). Thus the carrier state may be cones firmed by elevated serum activity of this enzyme, whereas with persistently normal values the oddso against it are at least 4 to 1 . In the detectionofo carriers by creatine kinase estimation, great cåre must be taken to minimize the possibility of fe्बise positive or negative results (Thompson, 1969) Necessary precautions are indicated in Table IV Should a carrier become pregnant, amniocentesiô may be used to determine the sex of the foetus, buf enzyme determinations on amniotic fluid are of $n \vec{Q}$ value in determining whether or not the child is affected.

Limb-girdle dystrophy

In this dystrophy raised levels of creatine kinase io

\begin{tabular}{lll}
\hline Timing of Specimens & Specimen Handling & Methodology \\
\hline $\begin{array}{lll}\text { During the evening, since levels are then } & \text { Analyse while fresh or after preservation } & \text { Sensitive established method, with thiol } \\
\text { maximal in carriers, whereas they may be } & \text { up to one week at } 4^{\circ} \text { or up to one month } & \text { included in substrate. Duplicate determina- } \\
\text { normal in a waking specimen, even in known } & \text { at }-18^{\circ} & \text { tion. }\end{array}$
\end{tabular}
carriers.

After normal activity which, in carriers, causes

the normal resting values to rise to abnormal

levels. It has no effect on values in normal subjects.

Not for at least 48 hours after severe, prolonged

exercise which raises the level in normal subjects.

Three specimens at weekly intervals to avoid the possibility of cyclical variation

Table IV Precautions to ensure accuracy in the detection of the carrier state of Duchenne muscular dystrophy 
the serum are found in about $75 \%$ of patients. The increase is less than in Duchenne dystrophy, levels averaging some 20 times normal. Such assays are of no value for detecting heterozygotes (Richterich, Rosin, Aebi, and Rossi, 1963).

\section{Facioscapulohumeral dystrophy}

In this condition elevation of serum creatine kinase occurs in some $80 \%$ of patients, levels averaging about five times normal.

\section{POLYMYOSITIS}

Polymyositis is an inflammatory myopathy which may be secondary to bacterial, viral, or parasitic infection of muscle, or may occur as a primary muscle disorder of unknown aetiology. The latter, so-called idiopathic polymyositis, occurs at any age and in both sexes, though females are more commonly affected. It is sometimes associated with skin disease, collagen disease, or malignancy. The onset may be acute, with fever, weakness, and muscle pain, or it may be insidious with progressive muscle weakness but no constitutional disturbance.

In idiopathic polymyositis, serum creatine kinase is elevated in about two-thirds of patients. Enzyme levels correlate with the activity of the disease. The highest values are found in affected children, and low or normal values occur in chronic, slowly progressive disease in adults. The levels may fluctuate widely, in contrast to the minor fluctuations seen in the muscular dystrophies (Richterich et al, 1963) from which this condition must frequently be distinguished.

Enzyme estimation may be used to assess the response of idiopathic polymyositis to steroid treatment. Raised serum creatine kinase activity may sometimes revert to normal within $\mathbf{4 8}$ hours if therapy is successful, and failure of enzyme levels to diminish indicates a lack of response or possibly the need for an increased dose of steroid.

In other varieties of polymyositis creatine kinase elevation is inconstant and relatively minor.

\section{OTHER MYOPATHIES}

\section{Myopathy in childhood}

A very large number of rare myopathies occur in infancy and childhood. In many of these (eg, central core disease and glycogenosis affecting muscle) moderate elevation of serum creatine kinase is common, so that assays are of no value in their differentiation. However, this mild elevation contrasts with the high levels found in the muscular dystrophies and with the normal values found in disorders of motor innervation, from which these rarer myopathies must be distinguished.

\section{Thyrotoxic and steroid myopathies}

The cause of myopathy in adults is commonly metabolic or endocrine, and the condition is found in some patients with thyrotoxicosis or receiving very large doses of steroids. Both these latter varieties are characterized by normal serum creatine kinase activity (Vassella, Richterich, and Rossi, 1965; Ekbom, Hed, Herdenstam, and Nygren, 1966). It is possible that thyroid and steroid hormones interfere with the permeability of the muscle fibre to the enzyme despite the presence of fibre damage.

Alcoholic myopathy and myopathy associated with malignant hyperpyrexia

Two varieties of myopathy in which elevation of serum creatine kinase has been observed recently merit special consideration; these are the syndromes that may accompany chronic alcoholism and the myopathy associated with malignant hyperpyrexia.

1 In chronic alcoholics, both acute and chronic muscle syndromes sometimes occur. The acute syndrome follows recent alcoholic excess and is characterized by painful, tender muscles, muscle cramps, and sometimes myoglobinuria. Over $80 \%$ of such patients show increased creatine kinase activity and such elevation is also found in a similar proportion of chronic alcoholics following acute intoxication even in the absence of previous or concomitant symptoms of muscle disease (Nygren, 1966; Perkoff, Dioso, Bleisch, and Klinkerfuss, 1967; Lafair and Myerson, 1968). The enzyme increases some three to five days following a drinking bout and returns to normal within two weeks if drinking is discontinued. Enzyme levels average some four times the upper limit of normal.

The chronic muscular syndrome is unrelated to recent heavy drinking, and is characterized by progressive weakness and wasting of proximal muscles, occasionally with muscle tenderness. In this condition increased creatine kinase activity is found in some $60 \%$ of patients, levels averaging twice the upper limit of normal (Perkoff et al, 1967; Lafair and Myerson, 1968).

Chronic alcoholics without evidence of chronic myopathy who have not been drinking recently show normal values.

2 Malignant hyperpyrexia is a rare condition which may follow the administration of a general anaesthetic, particularly when halothane or succinylcholine is used. The incidence is 1 per 15,000 anaesthetics and there is a $66 \%$ mortality (Kalow, Britt, Terreau, and Haist, 1970). The condition is commoner in children and young adults and in males and there is frequently a family history of the disease indicating inheritance as an autosomal dominant. Clinically it is characterized by impaired respiration, 
muscle spasms, shock, raised body temperature, and general convulsions. Extremely high serum levels of creatine kinase have been noted in the early postanaesthetic period (Denborough, Forster, Hudson, Carter, and Zapf, 1970b).

Increased serum levels are also found in relatives, some of whom are symptomless whereas others show a myopathy characterized by weakness and wasting, especially of the distal part of the thigh muscle (Isaacs and Barlow, 1970; Denborough, Ebeling, King, and Zapf, 1970a). It is advisable that relatives showing such increased serum levels be treated with caution should they require a general anaesthetic. It may be that persistent elevation of serum creatine kinase from any cause, particularly if associated with a myopathy, constitutes a special anaesthetic risk. It has been suggested that screening of the general public for elevated serum creatine kinase might be a means of preventing this disorder (Denborough $e t$ $a l, 1970$ a). However, apart from the obvious practical and economic difficulties of this procedure, its usefulness is questionable. Many healthy subjects show marked lability of serum values (Griffiths, 1966) and show an exaggeration of the elevation which normally occurs on exercise. Moreover, some apparently healthy patients with persistently elevated levels are said to have no predisposition to hyperpyrexia following general anaesthesia (Emery and Spikesman, 1970).

\section{Muscle Disease Secondary to Disorder of Motor In- nervation}

Disorders of motor innervation may result in muscular weakness and wasting resembling the myopathies. In these conditions, the most important of which are shown in Table II, serum creatine kinase activity is generally normal or shows only infrequent or modest elevation (Okinaka et al, 1961). When an increase does occur it is usually confined to the period when the neurological disorder is in an early progressive phase. Levels are generally less than twice the upper limit of normal.

In childhood, differentiation of neurogenic disorder from muscular dystrophy is generally easy because of the high creatine kinase values found in dystrophy, but in adults enzyme determinations may not always distinguish between them.

\section{Other Muscular Conditions Associated with Elevation of Serum Creatine Kinase}

\section{MUSCLE TRAUMA}

This may be accidental or the result of surgery and may result in pronounced elevation of serum creatine kinase. Values up to five times the upper limit of normal may also result from intramuscula injections (Hess et al, 1964). The possibility of suckp iatrogenic elevation must therefore always be borne in mind in the interpretation of raised serum levels?

Increased levels may be found following con vulsions (Fukuyama and Kawazura, cited b\% Okinaka, Sugita, Momoi, Toyokura, Watanabe Ebashi, and Ebashi, 1964) and in tetanus (Mullap and Dubowitz, 1964), the enzyme possibly orig nating from the convulsing muscle tissue. In tetanus however, serum levels may rise before the onset off convulsions, probably as a result of changes in the permeability of the muscle fibre membrane caused by tetanus toxin (Brody and Hatcher, 1967).

\section{Other Conditions}

In hypothermia (Maclean, Maclean, Griffiths, an $\vec{\alpha}$ Emslie-Smith, 1968), hypothyroidism (Graig and Ross, 1963), cerebrovascular disease (Achesoro James, Hutchinson, and Westhead, 1965; Kalbag, Park, and Pennington, 1966), and acute psychoses. (Meltzer, 1968) creatine kinase of muscle origin ma appear in the serum. In these, abnormal muscle ce\# permeability is thought to be the explanation although why it should occur in psychoses or cerebrovascular disease is obscure.

In hypothyroidism some $80 \%$ of patients stô raised values, which average eight times the uppes limit of normal. There is an inverse relations奥i between creatine kinase and protein-bound iodinn levels in serum (Graig and Smith, 1965) and it has been suggested that thyroid hormone normall influences muscle cell permeability to the enzyme se that, when the hormone level is reduced, permeabilit is increased.

Finally, it should be remembered that physie logical elevation occurs in early childhood (Okinakia. et al, 1964) in the early post-partum period (Hughes? 1963), and following prolonged severe exercise (Baumann, Escher, and Richterich, 1962), and that. elevation of cardiac origin may result from hea disease (Dreyfus et al, 1960).

\section{References}

Acheson, J., James, D. C., Hutchinson, E. C., and Westhead, R. (1965 Serum-creatine-kinase levels in cerebral vascular diseaseo Lancet, 1, 1306-1307.

Aebi, U., Richterich, R., Stillhart, H., Colombo, J. P. and Rossi, 苂 (1961). Progressive Muskeldystrophie. III. Serumenzyme bei dex Muskeldystrophie im Kindesalter. Helv. paediat. Acta, 16, 54B 564.

Agostoni, A., Ideo, G., and Stabilini, R. (1965). Serum $\gamma$-glutam transpeptidase activity in myocardial infarction. Brit. Heart 27, 688-690.

Agress, C. M. (1959). Evaluation of the transaminase test. Amer. $\bar{D}$ Cardiol., 3, 74-93.

Baumann, P., Escher, J., and Richterich, R. G. (1962). Das Verhaltẹn von Serum-Enzymen bei Sportlichen Leistungen. Schweiz. Z Sportmed., 10, 33-51. 
Brody, I. A., and Hatcher, M. A. (1967). Origin of increased serum creatine phosphokinase in tetanus. Arch. Neurol., 16, 89-93.

Chesler, E. (1958). Serum glutamic-oxalacetic transaminase levels in diphtheritic myocarditis. Brit. Heart J., 20, 244-248.

Chinsky, M., and Sherry, S. (1957). Serum transaminases as a diagnostic aid. A.M.A. Arch. intern. Med., 99, 556-568.

Cohen, L., Djordjevich, J., and Ormiste, V. (1964). Serum lactic dehydrogenase isozyme patterns in cardiovascular and other diseases, with particular reference to acute myocardial infarction. J. Lab. clin. Med., 64, 355-374.

Dack, S. (1963). Postoperative myocardial infarction. Amer. J. Cardiol., 12, 423-430.

Dempsey, J. J., and Salem, H. H. (1966). An enzymatic electrocardiographic study on toxicity of dehydroemetine. Brit. Heart J., 28, 505-511.

Denborough, M. A., Ebeling, P., King, J. O., and Zapf, P. (1970a). Myopathy and malignant hyperpyrexia. Lancet, 1, 1138-1140.

Denborough, M. A., Forster, J. F. A., Hudson, M. C., Carter, N. G., and Zapf, P. (1970b). Biochemical changes in malignant hyperpyrexia. Lancet, 1, 1137-1138.

Dreyfus, J. C., and Schapira, G. (1955). L'activité transaminasique du sérum au cours de myopathies. C.R. Soc. Biol. (Paris), 149, 1934-1935.

Dreyfus, J. C., Schapira, G., and Schapira, F. (1958). Serum enzymes in the physiopathology of muscle. Ann. N.Y. Acad. Sci., 75, 235-249.

Dreyfus, J. C., Schapira, G., Resnais, J., and Scebat, L. (1960). La créatine-kinase sérique dans le diagnostic de l'infarctus myocardique. Rev. franc. Etud. clin. biol., 5, 386-387.

Ebashi, S., Toyokura, Y., Momoi, H., and Sugita, H. (1959). High creatine phosphokinase activity of sera of progressive muscular dystrophy. J. Biochem., 46, 103-104.

Ekbom, K., Hed, R., Herdenstam, C.-G. P., and Nygren, A. (1966). The serum creatine phosphokinase activity and the Achilles reflex in hyperthyroidism and hypothyroidism. Acta med. scand., 179, 433-440.

Emery, A. E. H., and Spikesman, A. M. (1970). Serum creatine kinase levels. Brit. med. J., 2, 790.

Englhardt-Gölkel, A., Löbel, R., Seitz, W., and Woller, I. (1958). Uber das Verhalten und die Herkunft glykolytischer Serumenzyme beim Menschen und ihre diagnostische Bedeutung. Klin.Wschr., $36,462-468$.

Graig, F. A., and Ross, G. (1963). Serum creatine-phosphokinase in thyroid disease. Metabolism, 12, 57-59.

Graig, F. A., and Smith, J. C. (1965). Serum creatine phosphokinase activity in altered thyroid states. J. clin. Endocr., 25, 723-731.

Goble, A. J., and O'Brien, E. N. (1958). Acute myocardial ischaemia, significance of plasma transaminase activity. Lancet, 2, 873877.

Griffiths, P. D. (1966). Serum levels of ATP: creatine phosphotransferase (creatine kinase). The normal range and effect of muscular activity. Clin. chim. Acta, 13, 413-420.

Hedworth-Whitty, R., Whitfield, J. B., and Richardson, R. W. (1967). Serum $\gamma$-glutamyl transpeptidase activity in myocardial ischaemia. Brit. Heart J., 29, 432-438.

Hess, J. W., MacDonald, R. P., Frederick, R. J., Jones, R. N., Neely, J., and Gross, D. (1964). Serum creatine phosphokinase (CPK) activity in disorders of heart and skeletal muscle. Ann. intern. Med., 61, 1015-1028.

Hughes, B. P. (1963). Serum enzyme studies with special reference to the Duchenne type dystrophy. In Research in Muscular Dystrophy: The Proceedings of the Second Symposium (Muscular Dystrophy Group), pp. 167-179. Pitman, London.

Hunter, P. R., Endrey-Walder, P., Bauer, G. E., and Stephens, F. O. (1968). Myocardial infarction following surgical operation. Brit. med. J., 4, 725-728.

Isaacs, H., and Barlow, M. B. (1970). Malignant hyperpyrexia during anaesthesia: possible association with subclinical myopathy. Brit. med. J., 1, 275-277.

Kalbag, R. M., Park, D. C., and Pennington, R. J. (1966). Serum creatine kinase after head injuries and strokes. Proc. Ass. clin. Biochem., 4, 88-89.

Kalow, W., Britt, B. A., Terreau, M. E., and Haist, C. (1970). Metabolic error of muscle metabolism after recovery from malignant hyperthermia. Lancet, 2, 895-898.

Kibe, O., and Nilsson, N. J. (1967). Observations on the diagnostic and prognostic value of some enzyme tests in myocardial infarction. Acta med. scand., 182, 597-610.
Killen, D. A. (1968). Serum enzyme elevations: a diagnostic test for acute myocardial infarction during the early post operative period. Arch. Surg., 96, 200-210.

King, J., and Waind, A. P. B. (1960). Lactic dehydrogenase activity in acute myocardial infarction. Brit. med. J., 2, 1361-1363.

LaDue, J. S., Wróblewski, F., and Karmen, A. (1954). Serum glutamic oxaloacetic transaminase activity in human acute transmural myocardial infarction. Science, 120, 497-499.

LaDue, J. S., and Wróblewski, F. (1955). The significance of the serum glutamic oxaloacetic transaminase activity following acute myocardial infarction. Circulation, 11, 871-877.

Lafair, J. S., and Myerson, R. M. (1968). Alcoholic myopathy. With special reference to the significance of creatine phosphokinase. Arch. intern. Med., 122, 417-422.

Maclean, D., Griffiths, P. D., and Emslie-Smith, D. (1968). Serumenzymes in relation to electrocardiographic changes in accidental hypothermia. Lancet, 2, 1226-1270.

Mager, M., Blatt, W. F., and Abelmann, W. H. (1966). The use of cellulose acetate for the electrophoretic separation and quantitation of serum lactic dehydrogenase isozymes in normal and pathologic states. Clin. chim. Acta, 14, 689-697.

Meltzer, H. (1968). Creatine kinase and aldolase in serum: abnormality common to acute psychoses. Science, 159, 1368-1370.

Møller, C. E., and Raabo, E. (1964). Diagnostic use of fractionated lactic dehydrogenase activity (LDH) in myocardial infarction. Acta med. scand., 175, 31-42.

Mullan, D., and Dubowitz, V. (1964). Serum enzymes in diagnosis of tetanus. Lancet, 2, 505-506.

Myhre, E., and Rasmussen, K. (1970). Serum-lactic-dehydrogenase activity and intravascular haemolysis. Lancet, $1,355$.

Nora, J. J., Cooley, D. A., Johnson, B. L., Watson, S. C., and Milam, J. D. (1969). Lactic dehydrogenase isozymes in human cardiac transplantation. Science, 164, 1079-1080.

Nutter, D. O., Trujillo, N. P., and Evans, J. M. (1966). The isoenzymes of lactic dehydrogenase. I. Myocardial infarction and coronary insufficiency. Amer. Heart J., 72, 315-324.

Nydick, I., Tang, J., Stollerman, G. H., Wróblewski, F., and LaDue. J. S. (1955). The influence of rheumatic fever on serum concentrations of the enzyme, glutamic-oxalacetic transaminase. Circulation, 12, 795-806.

Nygren, A. (1966). Serum creatine phosphokinase activity in chronic alcoholism, in connection with acute alcoholic intoxication. Acta med. scand., 179 623-630.

Okinaka, S., Kumagai, H., Ebashi, S., Sugita, H., Momoi, H., Toyokura, Y., and Fujie, Y. (1961). Serum creatine phosphokinase activity: in progressive muscular dystrophy and neuromuscular diseases. Arch. Neurol., 4, 520-525.

Okinaka, S., Sugita, H., Momoi, H., Toyokura, Y., Watanabe, T., Ebashi, F., and Ebashi, S. (1964). Cysteine-stimulated serum creatine kinase in health and disease. J. Lab. clin. Med., 64, 299-305

Pearson, C. M. (1963). Muscular dystrophy: review and recent observations. Amer. J. med., 35, 632-645.

Perkoff, G. T., Dioso, M. M., Bleisch, V., and Klinkerfuss, G. (1967). A spectrum of myopathy associated with alcoholism. I. Clinical and laboratory features. Ann. intern. Med., 67, 481-492.

Ravens, K. G., Gudbjarnason, S., Cowan, C. M., and Bing, R. J. (1969). Gammaglutamyl transpeptidase in myocardial infarction. Circulation, 39, 693-700.

Resnik, W. H. (1962). Preinfarction angina. Mod. Con. cardiovasc., 31, 751-761.

Richterich, R., Burger, A., and Weber, H. (1962). Die Inaktivierung der Lactat-Dehydrogenase durch Harnstoff. I. Selektive Hemmung der elektrophoretisch langsam mandernden isoenzyme. Helv. physiol. Acta, 20, 78-80.

Richterich, R., Gautier, E., Egli, W., Zuppinger, K., and Rossi, E. (1961). Progressive Muskeldystrophie. I. Die Heterogenität der Serum-Lactat-Dehydrogenase. Klin. Wschr., 39, 346-352.

Richterich, R., Rosin, S., Aebi, U., and Rossi, E. (1963). Progressive muscular dystrophy. $V$. The identification of the carrier state in the Duchenne type by serum creatine kinase determination. Amer. J. hum. Genet., 15, 133-154.

Rosalki, S. B. (1963). Serum a-hydroxybutyrate dehydrogenase: a new test for myocardial infarction. Brit. Heart J., 25, 795-802.

Rosalki, S. B., Rau, D., Lehmann, D., and Prentice, M. (1970). Determination of serum $\gamma$-glutamyl transpeptidase activity and its clinical applications. Ann. clin. Biochem., 7, 143-147.

Rosalki, S. B., and Wilkinson, J. H. (1960). Reduction of a-ketobutyrate by human serum. Nature (Lond.), 188, 1110-1111. 
Runde, I., and Dale, J. (1966). Serum enzymes in acute tachycardia. Acta med. scand., 179, 535-541.

Schapira, G., and Dreyfus, J. C. (1957). Lacticodéhydrase plasmatique au cours des myopathies. C.R. Soc. Biol. (Paris), 151, 22-23.

Sibley, J. A., and Lehninger, A. L. (1949). Aldolase in the serum and tissues of tumor-bearing animals. J. nat. Cancer Inst., 9, 303309.

Smith, A. F. (1967). Diagnostic value of serum-creatine-kinase in a coronary-care unit. Lancet, 2, 178-182.

Thomson, W. H. S. (1969). The biochemical identification of the carrier state in $\mathrm{X}$-linked recessive (Duchenne) muscular dystrophy. Clin. chim. Acta, 26, 207-221.

Thompson, M. W., Murphy, E. G., and McAlpine, P. J. (1967). An assessment of the creatine kinase test in the detection of carriers of Duchenne muscular dystrophy. J. Pediat., 71, 82-93.

Vassella, F., Richterich, R., and Rossi, E. (1965). The diagnostic value of serum creatine kinase in neuromuscular and muscular disease. Pediatrics, 35, 322-330.

Vesell, E. S., and Bearn, A. G. (1957). Localization of lactic acid dehydrogenase activity in serum fractions. Proc. Soc. exp. Biol. (N.Y.), 94, 96-99.
Wacker, W. E. C., Ulmer, D. D., and Vallee, B. (1956). Metallat enzymes and myocardial infarction. II. Malic and lactic dehydrogenase activities and zinc concentrations in serum. $N$ Engl. J. Med., 255, 449-455.

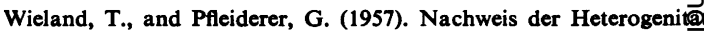
von Milchsăure-dehydrogenasen verschiedenen Ursprung durch Trägerelektrophorese. Biochem. Z., 329, 112-116.

Wieme, R. J. (1959). Studies on Agar Gel Electrophoresis. Arscia Brussels.

Wilkie, J. (1969). Serum aminotranspherase levels in aortic dissectiợ Lancet, 1, 261-262.

Wróblewski, F., and Gregory, K. F. (1961). Lactic dehydrogena isozymes and their distribution in normal tissues and plasroa and in disease states. Ann. N.Y. Acad. Sci., 94, 912-932.

Wróblewski, F., and LaDue, J. S. (1956). Serum glutamic pyruvic transaminase in cardiac and hepatic disease. Proc. Soc. exp Biol. (N.Y.), 91, 569-571.

Wróblewski, F., Ross, C., and Gregory, K. (1960). Isoenzymes año myocardial infarction. New Engl. J. Med., 263, 531-536. 